\title{
SULFUR REDUCING BACTERIA FROM COAL PITS WASTE HEAPS OF CHERVONOGRAD MINING REGION
}

\author{
S. V. Diakiv', S. O. Hnatush ${ }^{1}$, O. M. Moroz ${ }^{1}$, O. Ya. Prypin ${ }^{1}$, \\ O. R. Kulachkovskyi", V. Ye. Bodnaruk ${ }^{2}$ \\ ${ }^{1}$ Ivan Franko National University of Lviv, Hrushevskyi St., 4, Lviv 79005, Ukraine \\ ${ }^{2}$ Lviv National University of Veterinary Medicine and Biotechnologies named after S. Z. Gzhytskyi \\ Pekarska St., 50, Lviv 79010, Ukraine \\ e-mail: kuzmishyna_s_@ukr.net
}

Sulfur reducing bacteria from coal pits waste heaps of Chervonograd minig region were isolated and their seasonal number changes were established. Sulfur reducing bacteria number increases during cold season both at the end of vegetation season, depending on gangue humidity as well as on substrate temperature. The forty sulfur reducing bacteria isolates were selected. According to the highest biomass acumulation and hydrogen sulfide production for the following identification two strains were chosen. The morpho-physiological characteristics of isolated strains SV 30 and SV 35 were investigated. In accordance with obtained data, we assumed isolated strain SV 30 to be identified as genus Desulfuromusa, meanwhile SV 35 - Geobacter. After the seventh day of cultivation, the highest sulfur reducing activity of both strains was observed. Due to the metabolization ability of wide range of pollutants isolated sulfur reducing bacteria are perspective for application in environmental remediation technologies with biological methods.

Keywords: sulfur reducing bacteria, Geobacter, Desulfuromusa, coal pits waste heaps.

\section{INTRODUCTION}

Composited gangues from coal pits waste heaps consist of mudstone, siltstone, sandstone, coal, pyrite, sulfur [2]. Under the influence of high temperature and limited oxygen conditions pyrite decomposes to sulfur dioxide. Sulfuric acid and ferum-, manganese containing compounds are formed at the presence of water [38]. Obviously, in the sulfur compounds circulation including alternation of oxidation, reduction and transformation without changing the valence, microorganisms from gangues are involved [19]. Reduction of elemental sulfur occurs during sulfur respiration by sulfur reducing bacteria from waste heaps gangue. Molecular hydrogen or organic substrates are electron donors, while elemental sulfur, thiosulfate, tetrathionate, sulfite, polysulfide, heavy metals (HM) etc. are the terminal acceptors. Sulfur reducing bacteria produce hydrogen 
sulfide during sulfur reduction dissimilation. Hydrogen sulfide reacts with HM ions, forming almost insoluble sulfides [14].

Dissimilatory sulfur reduction is carried out by meso- and thermophilic eubacteria of domain Bacteria and by hyperthermophilic bacteria of domain Archaea, that are widespread in anoxic water sediments, soils, hot springs. Sulfur respiration could be supported either by obligate anaerobic (genus Desulfuromonas, Desulfurella, Desulfuromusa, Geobacter, Pelobacter) or by microaerophilic and aerobic (genus Wolinella, Shewanella, Campylobacter, Sulfospirillum, Alteromonas, Pseudomonas) bacteria (Tab. 1) [16, 28, 30]. The most of representatives of Desulfuromonaceae and Geobacteraceae reduce sulfur compounds as well as some metals with variable valence [8, 21, 23, 25-27, 34] and support chlorine and nitrogen reduction [4, 15, 32].

Excessive HM accumulation in the substrate breaks the course of natural processes, slowing the natural reclamation of area. HM mobility regulation is possible due to fixing or increasing their solubility owing to interaction with gangue compounds. This leads to following organometallic or inorganic complexes formation: biogenic hydrogen sulfide, carbonate- and phosphate-ions [12, 18, 23, 24]. Therefore, isolation of sulfur reducing bacteria strains from waste heaps gangue with their following identification, research of particularities of its metabolism such as sulfur reducing activity are important for planning and developing waste heaps remediation.

The purpose of our research was isolation of sulfur reducing bacteria from coal pits waste heaps of Chervonograd mining region and investigation of their morpho-physiological characteristics.

\section{MATERIALS AND METHODS}

20 gangue samples from 3 waste heaps (main heap of Central enrichment plant (CEP), waste heaps of coal pits "Vizejska" and "Nadija") were taken with the aim of sulfur reducing bacteria isolation. We selected patterns of bare substrate (BS) and from areas under the mosses (UM) of black (still not overburn gangue) and red (overburn gangue) colors, that differ by $\mathrm{pH}$ value and chemical content [2]. Gangue sample with mass $3 \mathrm{~g}$ was put into $30 \mathrm{ml}$ of sterile saline solution. Cultivation on Kravtsov-Sorokin medium without $\mathrm{SO}_{4}{ }^{2-}(\mathrm{pH} 7.0-7.5)$ was carried out from the series of dilutions sowings. Bacteria were incubated in $25 \mathrm{ml}$ tubes, which were tightly closed by rubber stoppers at thermostat under $+28{ }^{\circ} \mathrm{C}$ [42]. Bacteria were grown on Postgate $\mathrm{C}$ agar medium $(\mathrm{pH}$ 7.0-7.5) with sodium lactate $(6 \mathrm{~g} / \mathrm{l})$ for investigation its physiological and biochemical properties. To identify and count colonies of sulfur reducing bacteria iron chloride was added to medium, that led to FeS formation and caused black color of colonies [36].

Biomass was determined by colorimetric method (with application of photoelectric colorimeter KFK-3, wavelenght $340 \mathrm{~nm}$, cuvette with $3 \mathrm{~mm}$ optical way) by using the calibration curve. For investigation by electron microscopy cells were twice washed by distilled water, precipitated by centrifugation for $10000 \mathrm{rev} . / \mathrm{min}$ during 15 minutes. Cells were fixed by $1.5 \% \mathrm{OsO}_{4}$ solution in cacodylate buffer $(\mathrm{pH} \mathrm{7.2)} \mathrm{during} 90$ minutes at $0^{\circ} \mathrm{C}$. Fixed cells were washed and rehydrated in solutions with increasing concentrations of ethanol and propylene oxide. Samples were transferred into epoxy resin Epon 812. Cells slices were prepared with ultramickrotome UMTP-6 and then contrasted with lead citrate by Reynolds [33]. Viewing and photographing of samples was performed with transmission electron microscope PEM-100 at $75 \mathrm{kV}$ accelerating voltage. Sulfur reducing bacteria identification was carried out according to morpho-physiological characteristics [17]. Gram staining conducted according to the method [8].

ISSN 1996-4536 (print) • ISSN 2311-0783 (on-line) • Біологічні Студії / Studia Biologica • 2016 • Том 10/№2 • С. 63-76 


\section{Table 1. Sulfur reducing bacteria of Desulfuromonadales order}

\section{Таблиця 1. Сірковідновлювальні бактерії порядку Desulfuromonadales}

\begin{tabular}{|c|c|c|}
\hline Genus & Species & References \\
\hline \multicolumn{3}{|c|}{ Family Desulfuromonadaceae } \\
\hline \multirow[t]{9}{*}{ Desulfuromonas } & D. acetexigens & Finster et al., 1994 \\
\hline & D. acetoxidans & Pfennig and Biebl, 1976 \\
\hline & D. carbonis & Thuy et al, 2015 \\
\hline & D. chloroethenica & Krumholz, 1997 \\
\hline & D. michiganensis & Sung et al., 2003 \\
\hline & D. palmitatis & Coates et al., 1995 \\
\hline & D. soudanensis. & Badalamenti et al., 2016 \\
\hline & D. svalbardensis & Vandieken et al., 2006 \\
\hline & D. thiophila & Finster et al., 1997 \\
\hline \multirow[t]{4}{*}{ Desulfuromusa } & D. bakii & Liesack and Finster 1994 \\
\hline & D. ferrireducens & Vandieken et al., 2006 \\
\hline & D. kysingii & Liesack and Finster, 1994 \\
\hline & D. succinoxidans & Liesack and Finster, 1994 \\
\hline \multicolumn{3}{|c|}{ Family Geobacteraceae } \\
\hline \multirow[t]{21}{*}{ Geobacter } & G. anodireducens & Sun et al., 2014 \\
\hline & G. argillaceus & Shelobolina et al., 2007 \\
\hline & G. bemidjiensis & Nevin et al., 2005 \\
\hline & G. bremensis & Straub and Buchholz-Cleven,2001 \\
\hline & G. chapellei & Coates et al., 2001 \\
\hline & G. daltonii & Prakash et al., 2010 \\
\hline & G. grbiciae & Coates et al., 2001 \\
\hline & G. hydrogenophilus & Coates et al., 2001 \\
\hline & G. Iovleyi & Sung et al., 2009 \\
\hline & G. Iuticola & Viulu et al., 2013 \\
\hline & G. metallireducens & Lovley et al., 1995 \\
\hline & G. pelophilus & Straub and Buchholz-Cleven,2001 \\
\hline & G. pickeringii & Shelobolina et al., 2007 \\
\hline & G. psychrophilus & Nevin et al., 2005 \\
\hline & G. soli & Zhou et al., 2014 \\
\hline & G. sulfurreducens & Caccavo et al., 1995 \\
\hline & G. sulfurreducens subsp. ethanolicus & Viulu et al., 2014 \\
\hline & G. sulfurreducens subsp. Sulfurreducens & Viulu et al,. 2014 \\
\hline & G. thiogenes & (De Wever et al., 2001) Nevin et al., 2007 \\
\hline & G. toluenoxydans & Kunapuli et al., 2010 \\
\hline & G. uraniireducens & Shelobolina et al., 2008 \\
\hline \multirow[t]{2}{*}{ Geoalkalibacter } & G. ferrihydriticus & Zavarzina et al., 2006 \\
\hline & G. subterraneus & Greene et al., 2009 \\
\hline Geopsychrobacter & G. electrodiphilus & Holmes et al., 2004 \\
\hline Geothermobacter & G. ehrlichii & Kashefi et al. 2005 \\
\hline \multicolumn{3}{|c|}{ Family Pelobacteraceae } \\
\hline Malonomonas & M. rubra & Dehning and Schink, 1990 \\
\hline \multirow[t]{7}{*}{ Pelobacter } & $P$. acetylenicus & Schink, 1986 \\
\hline & $P$. acidigallici & Schink and Pfennig, 1983 \\
\hline & P. carbinolicus & Schink, 1984 \\
\hline & P. massiliensis & Schnell et al., 1991 \\
\hline & P. propionicus & Schink, 1984 \\
\hline & $P$. seleniigenes & Narasingarao and Häggblom, 2007 \\
\hline & $P$. venetianus & Schink and Stieb, 1984 \\
\hline
\end{tabular}

ISSN 1996-4536 (print) • ISSN 2311-0783 (on-line) • Біологічні Студії / Studia Biologica • 2016 • Том 10/№2 • С. 63-76 
In order to establish the usage of different carbon sources and electron donors the range of substances at concentration $53.57 \mathrm{mM}$ were added into Postgate $\mathrm{C}$ medium with sulfur and lack of sulfate-ions. There are sodium lactate (control), sodium acetate, sodium citrate, sodium piruvate, ascorbic, acetic, aspartic, benzoic, fumaric, malonic, nicotinic, stearic, succinic, palmitic and propionic acids, butanol, ethanol, fenol, mannitol, glucose, sucrose, fructose, alanine, glycine, urea.

To investigate the ability of bacteria to utilize different electron acceptors, fumaric (control) and malonic acids, sodium sulfate, sodium nitrate and sodium nitrite as well as sodium thiosulfate and sodium dithionite, cysteine, different metals compounds ( $\mathrm{Cr}(\mathrm{VI})$, $\mathrm{Mn}(\mathrm{VII}), \mathrm{Fe}(\mathrm{II}), \mathrm{Cu}(\mathrm{II}))$ were added into the medium at concentration $32.29 \mathrm{mM}$.

The presence of acetate-ion in the medium was established according to the described method [1].

For the determination of influence of temperature and $\mathrm{pH}$ on bacterial sulfur reducing activity bacteria cultivated at temperatures $+4,+16,+30,+37,+60{ }^{\circ} \mathrm{C}$ and $\mathrm{pH} 3.5$, $4.5,5.5,6.5,7.5,8.5,9.5$.

To establish sulfur reductase activity bacteria cells were separated from the medium by centrifugation at 8000 rev. per./min during 20 min. Enzymatic activity was measured by amount of hydrogen sulfide, produced during reaction [39]. The composition of reaction mixture was the following: potassium phosphate buffer $(\mathrm{pH} 7.5)-440 \mu \mathrm{l} ; \mathrm{S}^{0}$ 40 mg; 10 mM NADH ${ }^{+}-120 \mu \mathrm{l} ; 10$ mM EDTA - $120 \mu \mathrm{l}$; glycerin - $120 \mu \mathrm{l}$; culture fluid $400 \mu \mathrm{l}$. Reaction mixture was transferred into the tubes filled by argon. Incubation period was $10 \mathrm{~min}$. The reaction was started by adding $120 \mu \mathrm{NADH} \mathrm{N}^{+}$and finished by adding $200 \mu \mathrm{l}$ of $2 \mathrm{M} \mathrm{NaOH}$. Hydrogen sulfide was determined by the method of methylene blue formation [40].

Statistical data processing was performed with "Microsoft Excel 2007". Student coefficient was calculated for estimation the validity of differences between statistical characteristics of alternative data sets. The difference was claimed to be valid under the index of validity $p \leq 0.05$ [20].

\section{RESULTS}

Opened freshly deposited gangues are almost devoid of microorganisms. Nevertheless during the first year intensive gangue inoculation by microorganisms occur. Investigated waste heaps were deposited during years, thus they differs also by remediation levels. We observed changes of sulfur reducing bacteria number in December, April, July and October during 2014-2015.

In December, maximal rate of sulfur reducing bacteria was established in gangues from coal pit "Nadija" waste heap, minimal - from CEP waste heap (Tab. 2). In April the number of this group of microorganisms increase significantly in all gangue samples. After the analysis of sulfur reducing bacteria quantity in July, it was noticed, that only seven samples contained microorganisms. Moreover, all samples from CEP had no sulfur reducing bacteria. The probable causes were gangues self-heating and continued lack of precipitation, resulting in substrate drying. In October, the number of sulfur reducing bacteria continued to decrease: it was not higher than $110 \mathrm{CFU} / \mathrm{g}$ in absolutely dry gangue (ADG) in 15 samples. Therefore, al gangue samples contain sulfur reducing bacteria with their highest number during the vegetation season.

ISSN 1996-4536 (print) • ISSN 2311-0783 (on-line) • Біологічні Студії / Studia Biologica • 2016 • Том 10/№2 • С. 63-76 
Table 2. Changes in number of sulfur reducing bacteria on coal pits waste heaps depending on the season, [CFU/g ADG]

Таблиця 2. Зміна чисельності сірковідновлювальних бактерій породних відвалів вугільних шахт залежно від сезону, [КУО/ г АСП]

\begin{tabular}{|c|c|c|c|c|}
\hline Place of sampling & December & April & July & October \\
\hline \multicolumn{5}{|c|}{ CEP waste heap } \\
\hline Terrace, black gangue, UM Ceratodon sp. & $319 \pm 15$ & $2041 \pm 98$ & 0 & $19561 \pm 635$ \\
\hline Terrace, black gangue, BS & $10 \pm 1$ & $40000 \pm 1700$ & 0 & $16 \pm 1$ \\
\hline Main dump, black gangue, BS & $11 \pm 1$ & $1099 \pm 53$ & 0 & $6 \pm 1$ \\
\hline Main dump, red gangue, BS & $319 \pm 17$ & $16495 \pm 817$ & 0 & $6 \pm 1$ \\
\hline Freshly deposited gangue ${ }^{1}$, BS & $204 \pm 8$ & $108 \pm 4$ & 0 & $50 \pm 8$ \\
\hline \multicolumn{5}{|c|}{ Coal pit "Vizejska" waste heap } \\
\hline Top, red gangue, UM Polytrichum sp. & $91 \pm 5$ & $244 \pm 12$ & $25641 \pm 1314$ & $18 \pm 3$ \\
\hline Top, red gangue, BS & $296 \pm 13$ & $69231 \pm 321$ & $2564 \pm 98$ & $52 \pm 11$ \\
\hline Terrace, black gangue, UM Brachitecium sp. & $2041 \pm 102$ & $8602 \pm 370$ & $2809 \pm 146$ & $55 \pm 4$ \\
\hline Tepaca, black gangue, BS & $1776 \pm 86$ & $2353 \pm 122$ & 0 & $6 \pm 1$ \\
\hline Base, black gangue, UM Ceratodon sp. & $581 \pm 27$ & $112 \pm 7$ & 0 & $46 \pm 3$ \\
\hline Base, black gangue, UM Polytrichum sp. & $10 \pm 1$ & $8696 \pm 449$ & $575 \pm 29$ & $11824 \pm 546$ \\
\hline Base, black gangue, BS & $133 \pm 6$ & $238 \pm 8$ & 0 & $14752 \pm 717$ \\
\hline \multicolumn{5}{|c|}{ Coal pit "Nadija” waste heap } \\
\hline Top, black gangue, UM Polytrichum sp. & $112 \pm 6$ & $3409 \pm 163$ & 0 & $108 \pm 4$ \\
\hline Top, black gangue, BS & $505 \pm 26$ & $27551 \pm 814$ & $6030 \pm 255$ & $109 \pm 3$ \\
\hline Top, red gangue, UM Ceratodon sp. & $1392 \pm 70$ & 0 & 0 & $17 \pm 1$ \\
\hline Top, red gangue, BS & $1146 \pm 56$ & $34091 \pm 159$ & 0 & $16548 \pm 662$ \\
\hline Terrace, black gangue, UM, Ceratodon sp. & $34895 \pm 1691$ & $116 \pm 2$ & $20833 \pm 927$ & $17887 \pm 812$ \\
\hline Terrace, black gangue, BS & $11 \pm 1$ & 0 & 0 & $27 \pm 2$ \\
\hline Base, black gangue, UM Ceratodon sp. & $543 \pm 27$ & $24742 \pm 141$ & $54348 \pm 2739$ & $12 \pm 1$ \\
\hline Base, black gangue, BS & $115 \pm 5$ & $41237 \pm 2001$ & 0 & $23 \pm 2$ \\
\hline
\end{tabular}

Comments: CFU - colony forming units, BS - bare substrate, UM - under the mosses. ${ }^{1}$ - gangue, deposited in 2013 year

Примітки: $\mathrm{CFU}$ - колонієутворювальні одиниці, BS - оголений субстрат, UM - під мохом. ${ }^{1}$ - порода, насипана у 2013 p.

Isolation and selection of sulfur reducing bacteria have been conducted according to the intensity of the colonies color on agar medium as a result of ferum sulfide formation. Among 40 isolates 6 were selected. Then according to the highest biomass accumulation and the amount of hydrogen sulfide production two strains (SV 30 and SV 35) were chosen for following identification by morpho-physiological characteristics. 
The cells of both isolates are elongated rods, motile, non-spore-forming, gram-negative, support completely oxidation of organic substrates (to $\mathrm{CO}_{2}$ ) (Fig. 1).
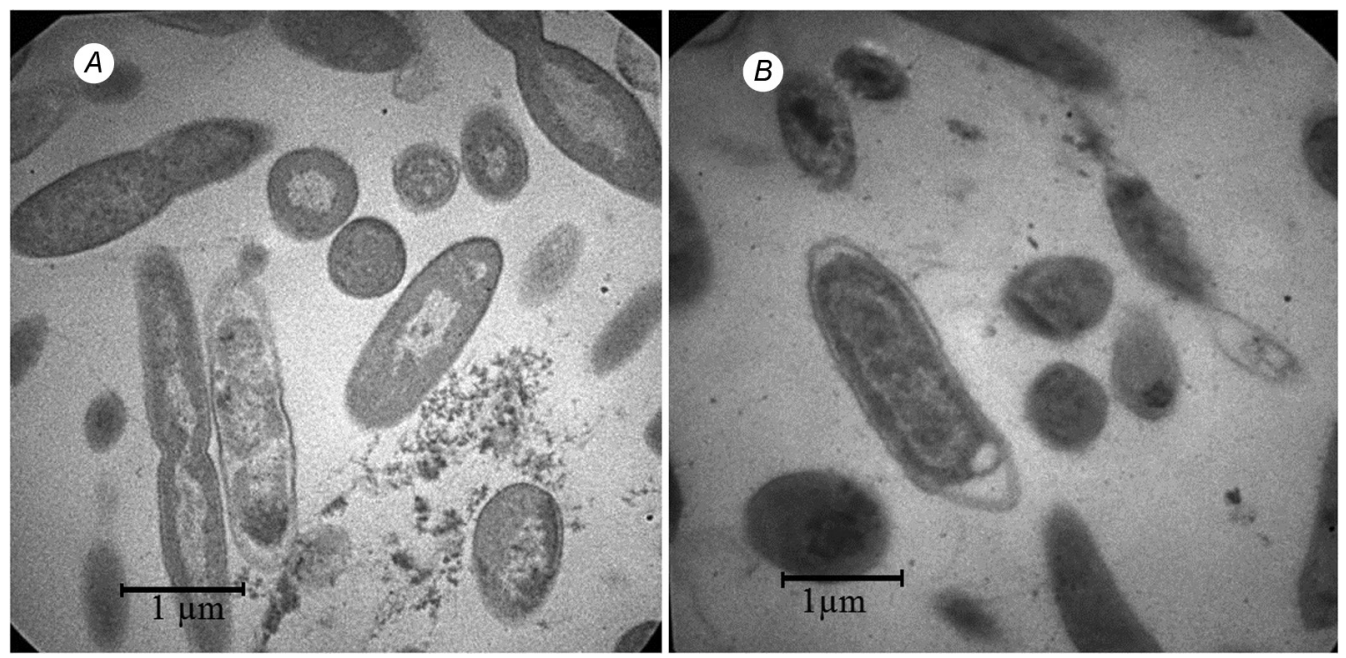

Fig. 1. Cells of sulfur reducing bacteria, that were isolated: $A-\mathrm{SV} 30 ; B-\mathrm{SV} 35$ (electron microscopy, $\times 10000)$

Рис. 1. Клітини виділених штамів сірковідновлювальних бактерій: $A$ - СВ 30; $B$ - СВ 35 (електронна мікроскопія, ×10 000)

Strain SV 30 accumulates the highest biomass at $25^{\circ} \mathrm{C}$ and $\mathrm{pH} 7.0$, meanwhile SV $35-$ at $28^{\circ} \mathrm{C}$ and $\mathrm{pH}$ 8.0. Thus both isolated strains are mesophilous, SV 30 is neutrophilous and SV 35 - moderate alkaliphilic.

The biomass accumulation and hydrogen sulfide production were studied to determine the ability of different electron donors and acceptors utilization by isolated SV 30 and SV 35 strains (Fig. 2). The highest biomass was accumulated on the seventh day. SV 30 strain produced the highest amount of hydrogen sulfide after two weeks of cultivation $(1.02 \pm 0.02 \mathrm{mM})$, and SV 35 strain - on the tenth day $(0.90 \pm 0.03 \mathrm{mM})$.

Bacterial utilization of different organic compounds as carbon sources and electron donors were investigated. SV 30 strain accumulated $0.73 \pm 0.04 \mathrm{~g} / \mathrm{l}$ biomass, producing $1.04 \pm 0.06 \mathrm{mM}$ of hydrogen sulfide and SV 35 strain $-0.69 \pm 0.02 \mathrm{~g} / \mathrm{l}$ with $0.82 \pm 0.04 \mathrm{mM}$ of hydrogen sulfide on the control medium (electron donor - lactate). Similar to control biomass were accumulated on the mediums with sodium acetate $(0.70 \pm 0.08$ and $0.67 \pm 0.03 \mathrm{~g} / \mathrm{l}$ respectively) and sodium citrate $(0.73 \pm 0.07$ and $0.61 \pm 0.01 \mathrm{~g} / \mathrm{l}$ respectively). SV 35 strain produced in 1.35 time higher amount of hydrogen sulfide in the case of citrate utilization. Utilization of fumaric acid as carbon source leaded to production in 1.28 and 1.49 times more hydrogen sulfide, compared to lactate usage. The usage of sodium pyruvate, acetic, ascorbic, malonic, stearic acids and glucose, alanine, mannitol, urea caused less biomass accumulation, compared to the control. Bacteria growth was not observed at presence of benzoic, nicotinic palmitic, propionic and succinic acids the same as butanol, ethanol. However ethanol usage caused the accumulation of $0.81 \pm 0.04 \mathrm{mM}$ of hydrogen sulfide by SV 30 strain. The fructose and sucrose usage (but without sulfur reducing) by SV 35 strain as well as glycine, aspartic acid and fenol by SV 30 strain made the significant differences between two isolated strains.

ISSN 1996-4536 (print) • ISSN 2311-0783 (on-line) • Біологічні Студії / Studia Biologica • 2016 • Том 10/№2 • C. $63-76$ 


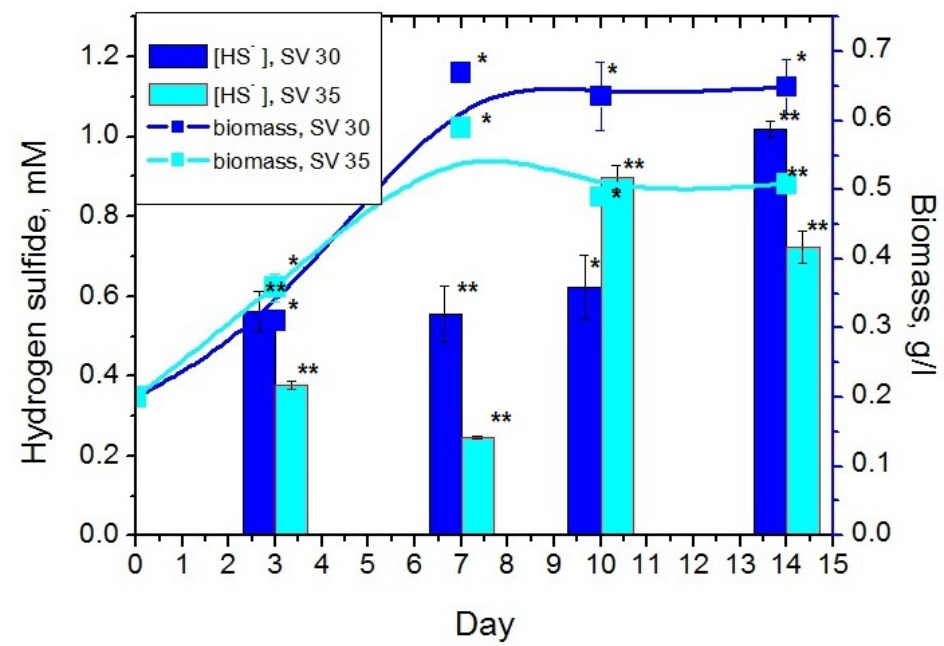

Fig. 2. Biomass growth and hydrogen sulfide production by SV 30 and SV 35 strains on the medium with sodium lactate and elemental sulfur during 14 days of cultivation. ${ }^{*}-p \leq 0.05, n=4 ;{ }^{* *}-p \leq 0.01$, $\mathrm{n}=4$ - significant biomass and hydrogen sulfide changes compared to an appropriate controls ( $0.2 \mathrm{~g} / \mathrm{l}$ - initial biomass, $0 \mathrm{mM} \mathrm{-} \mathrm{initial} \mathrm{hydrogen} \mathrm{sulfide} \mathrm{concentration).}$

Рис. 2. Нагромадження біомаси й утворення гідроген сульфіду штамами СВ 30 і СВ 35 у середовищі з натрій лактатом і елементною сіркою упродовж 14 діб культивування. * $-p \leq 0,05, n=4 ;{ }^{*}$ $\mathrm{p} \leq 0,01, \mathrm{n}=4$ - вірогідні зміни біомаси та гідроген сульфіду порівняно з відповідними контролями (0,2 г/л - біомаса засіву, 0 мМ - початкова концентрація гідроген сульфіду)

Sulfur reducing activity was not observed during strains cultivation on Postgate C medium with sodium sulfate, sodium thiosulfate and sodium dithionite or determined in small amounts on medium with cycteine. Since isolated strains could not use these compounds as terminal electron acceptors, therefore we can not identify them as genus Desulfomicrobium or Desulfovibrio. We reject genus Malomonas, because its representatives do not use inorganic substances as terminal electron acceptors [17].

The growth of both strains on medium with fumatare that simultaneously served as electrons donor and acceptor without elemental sulfur, was established (Fig. 3).

Bacteria are able of nitrate- and nitrite as electron acceptors reduction (Fig. 3). The applying of $32 \mathrm{mM}$ sodium nitrite on the tenth day of cultivation leaded to biomass lowering: in 2.40 (SV 30) and in 2.23 (SV 35) times less than during fumarate reduction. After the usage of sodium nitrate strains accumulated in 1.5 and 1.2 times smaller biomass compared to fumarate.

Isolated strains utilize heavy metals ions as electron acceptors (Fig. 4). The limit metals concentrations were following: chrome $-1 \mathrm{mM}$, manganese and ferum $-5 \mathrm{mM}$.

Absolutely inhibiting of biomass accumulation by strain SV 35 was observed after adding of $1 \mathrm{mM}$ of potassium dichromate applying. This also leaded to biomass lowering of SV 30 in 4.81 times comparatively with a control (fumarate). In the same time increasing the potassium permanganate content till $5 \mathrm{mM}$ caused the biomass growth of strain SV 30 in 1.31 times comparatively to the control. Ferric citrate applying leaded to noticeable biomass decrease: in 1.97 and 1.85 times - after 0,5 mM ferric citrate applying and in 5.42 and 10.76 times - after $5 \mathrm{mM}$.

The impact of temperature and $\mathrm{pH}$ value on biomass accumulation and hydrogen sulfide production by strain SV 30 was investigated (Fig. 5). Cells were grown at tem-

ISSN 1996-4536 (print) • ISSN 2311-0783 (on-line) • Біологічні Студії / Studia Biologica • 2016 • Том 10/№2 • С. 63-76 
perature from +4 till $+60{ }^{\circ} \mathrm{C}$ and $\mathrm{pH}$ value from 3.5 till 9.5. The highest biomass was accumulated at temperature from +16 till $+30{ }^{\circ} \mathrm{C}$ and $\mathrm{pH}$ 6.5. The highest amount of hydrogen sulfide was determined after 6 days of cultivation at $+37^{\circ} \mathrm{C}$ and $\mathrm{pH}$ value from 7.5 till 9.5 as well as at $+30^{\circ} \mathrm{C}$ and $\mathrm{pH} 7.5$.

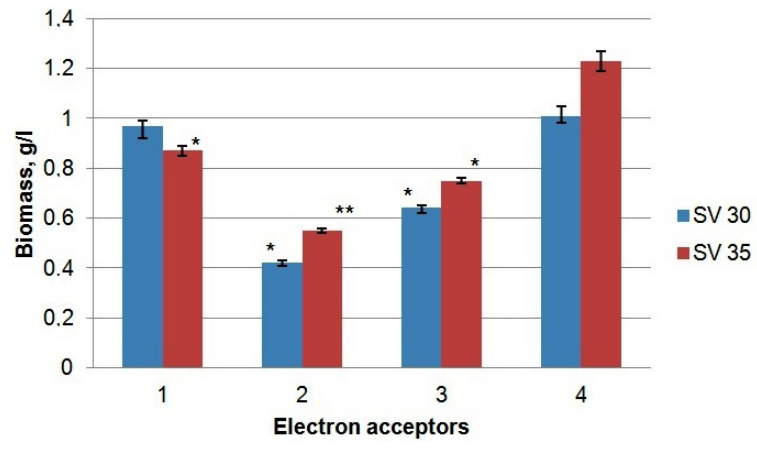

Fig. 3. Different electron acceptors utilization by sulfur reducing bacteria: 1 malate, $2-\mathrm{NO}_{2}^{-} ; 3-\mathrm{NO}_{3}^{-} ; 4-$ fumarate (control). $\left({ }^{*}-p \leq 0.05, n=3\right.$; ** $-\mathrm{p} \leq 0.01, \mathrm{n}=3-$ significant changes compared to the control)

Рис. 3. Використання сірковідновлювальними бактеріями різних акцепторів електронів: 1 - малат; 2 - $\mathrm{NO}_{2}$; $3-\mathrm{NO}_{3} ; 4-$ фуммарат (контроль). $\left({ }^{*}-p \leq 0,05, n=3 ;{ }^{*}-p \leq 0,01\right.$, $\mathrm{n}=3-$ вірогідні зміни порівняно з контролем)

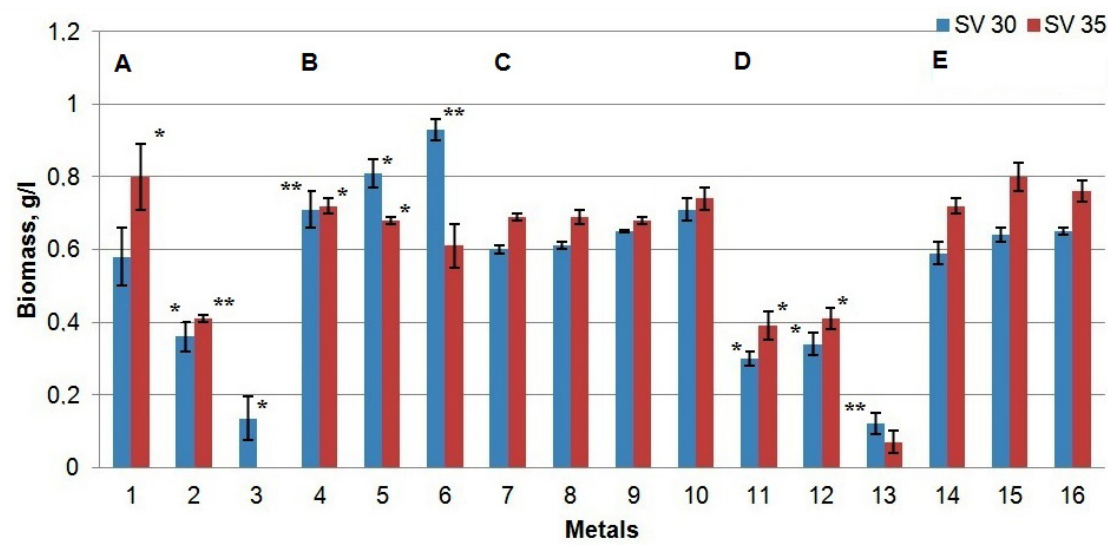

Fig. 4. Utilization of metal compounds as electron acceptors by sulfur reducing bacteria $(A-\mathrm{Cr}(\mathrm{VI}), B-$ $\mathrm{Mn}(\mathrm{IV}), D-\mathrm{Fe}$ (III); $C$ - control 1: electron donor - sodium lactate, acceptor - fumarate; $\mathrm{E}$ - control 2: electron donor - sodium citrate, acceptor - fumarate). 1-3- $\mathrm{Cr}(\mathrm{VI})$ concentration: 0,1 $\mathrm{mM}(1)$; 0,5 mM (2); $1 \mathrm{mM}$ (3). 4-6 - Mn (VI) concentration: 0,5 mM (4); $1 \mathrm{mM}(5) ; 5 \mathrm{mM}(6) .7-10$ - fumarate (donor - sodium lactate) concentration: $0,1 \mathrm{mM}$ (7); 0,5 mM (8); $1 \mathrm{mM}$ (9); $5 \mathrm{mM}$ (10). 11-13 - Fe (III) concentration: $0,5 \mathrm{mM}$ (11); $1 \mathrm{mM}(12) ; 5 \mathrm{mM}$ (13). 14-16 - fumarate (donor - sodium citrate) concentration: 0,5 mM (14); $1 \mathrm{mM}(15) ; 5 \mathrm{mM}(16),{ }^{*}-\mathrm{p} \leq 0.05, \mathrm{n}=3$; ${ }^{*}-\mathrm{p} \leq 0.01, \mathrm{n}=3$ - significant changes of indices $A$ and $B$ compared to control $C$ and $D$ indices - to control $E$

Рис. 4. Використання сірковідновлювальними бактеріями сполук металів як акцепторів електронів $(A-$ $\mathrm{Cr}(\mathrm{VI}), B$ - Mn (IV), D - Fe (III); C - контроль 1: донор електронів - натрій лактат, акцептор фумарат; E - контроль 2: донор електронів натрій цитрат, акцептор - фумарат). 1-3 - $\mathrm{Cr}$ (VI) у концентраціях: 0,1 мМ (1); 0,5 мМ (2); 1 мM (3). 4-6 - Mn (VI) у концентраціях: 0,5 мM (4); 1 мM (5); 5 мM (6). 7-10 - фуммарат (донор - Nа лактат) у концентраціях: 0,1 мM (7); 0,5 мM (8); 1 мM (9); 5 мM (10). 11-13 - Fe (III) у концентраціях: 0,5 мM (11); 1 мM (12); 5 мM (13). 14-16 - фумарат (донор - Na цитрат) у концентраціях: 0,5 мM (14); 1 мM (15); 5 мM (16). * $-p \leq 0,05, n=3 ;{ }^{* *}-p \leq$ $0,01, \mathrm{n}=3$ - вірогідні зміни показників $A$ і $B$ порівняно з контролем $C$ та показників $D$ - із контролем $E$ відповідно

Therefore, according to the temperature optimum and the ability to organic compounds complete oxidation (Tab. 3), we reject genus Desulfurella [17]. Since Pelobacter 
grows only by fermentation of a limited range of substrates that are relatively rare in most anaerobic environments (acetylene, acetoin, ethylene glycol, butanediol, ethanol, 2,3-butanediol and acetate) and do not uses saccharides as carbon sources and electron donors, consequently isolated strains could not belong to this genus [17, 25]. Geoalkalibacter, Geopsychrobacter and Geothermobacter were eliminated because of highly specific growth conditions (high $\mathrm{pH}$ value, $\mathrm{NaCl}$ need, temperature optimums respectively) [6, 9, 13, 45]. Isolated bacteria were not determined as genus Desulfuromonas due to morphological and physiological differences [17, 31].
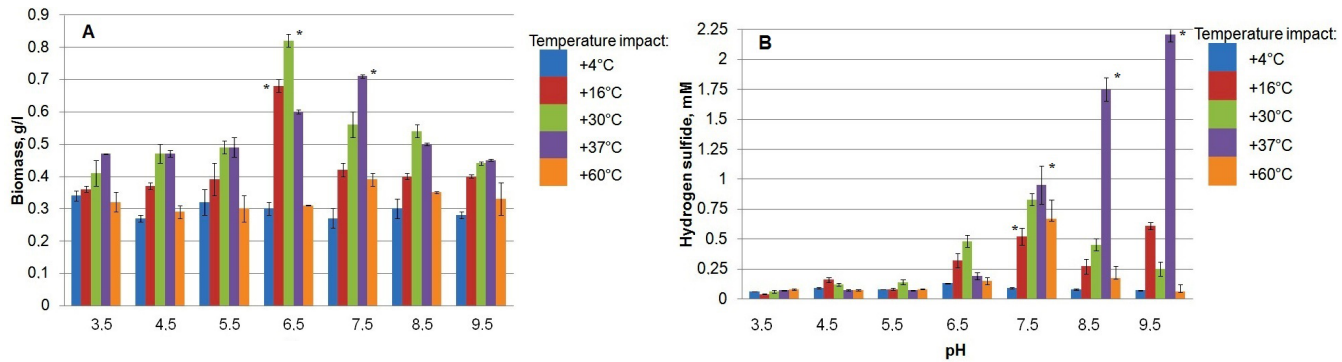

Fig. 5. Impact of temperature and $\mathrm{pH}$ value of medium on biomass growth $(A)$ and hydrogen sulfide production $(B)$ by SV 30 strain on Postgate $C$ medium with sodium lactate and elemental sulfur on the $6^{\text {th }}$ day of cultivation. ${ }^{*}-\mathrm{p} \leq 0.05, \mathrm{n}=3$ - significant changes compared to the control (at $30^{\circ} \mathrm{C}$ and $\mathrm{pH} 7.5$ )

Рис. 5. Вплив температури та $\mathrm{pH}$ середовища на нагромадження біомаси $(A)$ й утворення гідроген сульфріду $(B)$ штамом CB 30 у середовищі Постгейта С з натрій лактатом і елементною сіркою на 6 добу культивування. ${ }^{*}-\mathrm{p} \leq 0,05, \mathrm{n}=3$ - вірогідні зміни порівняно з контролем (за температури $30{ }^{\circ} \mathrm{C}$ та $\left.\mathrm{pH} 7,5\right)$

Table 3. Morpho-physiological characteristics of isolated SV $\mathbf{3 0}$ and SV $\mathbf{3 5}$ strains Таблиця 3. Морфофізіологічні характеристики виділених штамів СВ 30 і СВ 35

\begin{tabular}{|c|c|c|c|c|}
\hline Characteristic & CB 30 & CB 35 & Desulfuromusa & Geobacter \\
\hline Source & Gangue & Gangue & $\begin{array}{l}\text { Anoxic marine water } \\
\text { or estuarine muds }\end{array}$ & $\begin{array}{l}\text { Soil and water } \\
\text { sediments }\end{array}$ \\
\hline Morphology & Curved rods & Rods & Bananashaped & Curved rods \\
\hline Cell size, $\mu \mathrm{m}$ & $0.4-0.6 \times 1.5-2.4$ & $0.5-0.9 \times 1.7-2.5$ & $\begin{array}{l}0.4-0.8 \times \\
1-6\end{array}$ & $\begin{array}{c}0.3-0.5 \times \\
1.3-1.7\end{array}$ \\
\hline Motility & + & + & + & + \\
\hline Spore forming ability & - & - & - & - \\
\hline $\begin{array}{l}\text { Oxidation of organic } \\
\text { compounds }\end{array}$ & Complete & Complete & Complete & Complete \\
\hline $\begin{array}{l}\text { Temperature optimum, } \\
{ }^{\circ} \mathrm{C}\end{array}$ & 25 & 28 & 35 & 35 \\
\hline $\mathrm{pH}$ optimum & $7.0-7.5$ & $7.5-8.0$ & $6.5-7.0$ & $6.5-7.0$ \\
\hline Sulfurreductase & + & + & + & + \\
\hline \multicolumn{5}{|c|}{ Electron acceptors } \\
\hline $\mathrm{S}^{\circ}$ & + & + & + & + \\
\hline Malonic acid & + & + & + & + \\
\hline
\end{tabular}

ISSN 1996-4536 (print) • ISSN 2311-0783 (on-line) • Біологічні Студії / Studia Biologica • 2016 • Том 10/№2 • С. 63-76 
The end of the Table 3

\begin{tabular}{|c|c|c|c|c|}
\hline Fumaric acid & + & + & + & + \\
\hline Cysteine & - & - & - & NR \\
\hline $\mathrm{NO}_{2}^{-}$ & + & + & - & NR \\
\hline $\mathrm{NO}_{3}^{-}$ & + & + & $+/-$ & + \\
\hline $\mathrm{Cr}(\mathrm{VI})$ & + & + & NR & + \\
\hline $\mathrm{Mn}(\mathrm{VII})$ & + & + & NR & + \\
\hline $\mathrm{Fe}(\mathrm{III})$ & + & + & + & + \\
\hline $\mathrm{Cu}(\mathrm{II})$ & + & + & NR & NR \\
\hline $\mathrm{SO}_{4}{ }^{2-}$ & - & - & - & - \\
\hline $\mathrm{S}_{2} \mathrm{O}_{4}{ }^{2-}$ & - & - & - & NR \\
\hline $\mathrm{S}_{2} \mathrm{O}_{3}{ }^{2-}$ & - & - & - & NR \\
\hline \multicolumn{5}{|c|}{ Electron donors and carbon sources } \\
\hline Sodium acetate & + & + & NR & NR \\
\hline Sodium citrate & + & + & + & + (ferric citrate) \\
\hline Sodium lactate & + & + & + & + \\
\hline Sodium pyruvate & + & + & + & + \\
\hline Acetic acid & + & + & + & + \\
\hline Ascorbic acid & + & + & NR & NR \\
\hline Aspartic acid & + & - & + & NR \\
\hline Benzoic acid & - & - & NR & + \\
\hline Fumaric acid & + & + & + & + \\
\hline Malonic acid & + & + & + & + \\
\hline Nicotinic acid & - & - & NR & NR \\
\hline Palmitic acid & - & - & NR & NR \\
\hline Propionic acid & - & - & NR & NR \\
\hline Stearic acid & + & + & NR & NR \\
\hline Succinic acid & - & - & + & - \\
\hline Butanol & - & - & - & NR \\
\hline Ethanol & + & - & - & + \\
\hline Fenol & + & - & - & + \\
\hline Glucose & + & + & - & + \\
\hline Sucrose & - & $\begin{array}{c}+ \text { (not reduces } \\
\left.\mathrm{S}^{0}\right)\end{array}$ & - & NR \\
\hline Fructose & - & $\begin{array}{c}+(\text { not reduces } \\
\left.\mathrm{S}^{0}\right)\end{array}$ & - & NR \\
\hline Alanine & + & + & + & NR \\
\hline Glycine & + & - & + & NR \\
\hline Mannitol & + & + & - & + \\
\hline Urea & $\begin{array}{c}++(\text { not reduces } \\
\left.S^{0}\right)\end{array}$ & $\begin{array}{c}+(\text { not reduces } \\
\left.\mathrm{S}^{0}\right)\end{array}$ & NR & NR \\
\hline
\end{tabular}

Comments: NR - not reported in literature; "+" - utilized; "-“- not utilized

Примітки: NR - не повідомлено у першоджерелах; "+" - утилізують, “-” - не утилізують 


\section{CONCLUSION}

Therefore, there are sulfur reducing bacteria in waste heaps gangues. Their number increases during cold season both at the end of vegetation season, depending on gangue humidity as well as on substrate temperature. Isolated strains cells are rod-shaped, non-spore-forming, gram-negative, motile, provide completely oxidation of organic substrates, do not utilize sulfate-, thiosulfate- and dithionite-ions as electron acceptors, reduce only elemental sulfur. Another possible acceptors are malate, fumarate, nitriteand nitrate-ions both $\mathrm{Cr}(\mathrm{VI}), \mathrm{Mn}(\mathrm{VII})$ and Fe (III) compounds. However strains differ by the ability of usage of organic substrates as carbon sources and electron donors. Unlike strain SV 30, SV 35 utilizes fructose and sucrose, but neither aspartate and glycine, nor fenol and ethanol could be used by it. According to data obtained we assume the isolated strain SV 30 belongs to genus Desulfuromusa, meanwhile SV 35 - to Geobacter. The highest sulfur reducing activity of isolated strains was observed after the seventh day of cultivation: strain SV 30 produces maximum hydrogen sulfide up to $1.02 \pm 0.02$ $\mathrm{mM}$, and SV $35-0.90 \pm 0.03 \mathrm{mM}$. Due to the metabolization ability of wide range of pollutants isolated sulfur reducing bacteria are perspective for usage in environmental remediation technologies with biological methods.

1. Babko A. K., Pjatnytskyi I. V. Quantitative analysis. Kyiv: Vyshcha Shkola, 1974. 352 p. (In Ukrainian).

2. Baranov V. I. Ecological description of CEP coal pit waste heaps "CJSC Lvivsystemenergy" as an object for landscaping. Visnyk of Lviv University. Series Biology, 2008; 46: 172178. (In Ukrainian).

3. Coates J. D., Bhupathiraju V. K., Achenbach L. A. Geobacter hydrogenophilus, Geobacter chapellei and Geobacter grbiciae, three new, strictly anaerobic, dissimilatory Fe (III)-reducers. International Journal of Systematic and Evolutionary Microbiology, 2001; 51: 581-588.

4. Cole J.A., Ferguson S.J. Assimilatory and dissimilatory reduction of ammonia. The Nitrogen and Sulfur Cycles. Cambridge University Press, 1988; 42: 281-329.

5. Cummings D.E., Snoeyenbos-West O.L., Newby D.T. et al. Diversity of Geobacteraceae species inhabiting metal-polluted freshwater lake sediments ascertained by $16 \mathrm{~S}$ rDNA analyses. Microbial Ecology, 2003; 46: 257-269.

6. Greene A.C., Patel B.K., Yacob S. Geoalkalibacter subterraneus sp. nov., an anaerobic $\mathrm{Fe}$ (III)- and $\mathrm{Mn}$ (IV)-reducing bacterium from a petroleum reservoir, and emended descriptions of the family Desulfuromonadaceae and the genus Geoalkalibacter. International Journal of Systematic Bacteriology, 2009; 59: 781-785.

7. Gudz S.P., Hnatush S.O., Javorska G.V. et al. Practical Microbiology: manual for students. Lviv: NU of Lviv I. Franko, 2014. 436 p. (In Ukrainian).

8. Hedderich R., Klimer O., Kroger A. et al. Anaerobic respiration with elemental sulfur and with disulfides. FEMS Microbiology Reviews, 1999; 22: 353-381.

9. Holmes D.E., Nicoll J.S., Bond D.R. et al. Potential role of a novel psychrotolerant member of the family Geobacteraceae, Geopsychrobacter electrodiphilus gen. nov., sp. nov., in electricity production by a marine sediment fuel cell. Applied and Environmental Microbiology, 2004; 70: 6023-6030.

10. Holmes D.E., Giloteaux L., Chaurasia A.K. et. al. Evidence of Geobacter-associated phagein a uranium-contaminated aquifer. International Society for Sicrobial Ecology Journal, 2015; 9: 333-346.

11. Holmes D.E., O'neil R.A., Vrionis H.A. et al. Subsurface clade of Geobacteraceae that predominates in a diversity of $\mathrm{Fe}(\mathrm{III})$-reducing subsurface environments. International Society for Microbial Ecology Journal, 2007; 1: 663-677.

12. Iutynska G.O. Soil microbiology: Manual. Kyiv: Aristej, 2006. 284 p. (In Ukrainian).

ISSN 1996-4536 (print) • ISSN 2311-0783 (on-line) • Біологічні Студії / Studia Biologica • 2016 • Том 10/№2 • C. 63-76 
13. Kashefi K., Holmes D.E., Baross J.A. et al. Thermophily in the Geobacteraceae: Geothermobacter ehrlichii gen. nov., sp. nov., a novel thermophilic member of the Geobacteraceae from the „Bag City” hydrothermal vent. Applied and Environmental Microbiology, 2003; 69: 2985-2993.

14. Kozlova I.P., Radchenko O.S., Stepura I.G. et al. Microorganisms geochemical activity and it's applied aspects: tutorial labeled with MES. Kyiv: Naukova Dumka, 2008. 528 p.

15. Krumholz, L.R. Desulfuromonas chloroethenica sp. nov. uses tetrachloroethylene and trichloroethylene as electron acceptors. International Journal of Systematic Bacteriology, 1997; 47: 1262-1263.

16. Kuever J., Rainey F., Widdel F. Class IV. Deltaproteobacteria class nov. Bergey's Manual of Systematic Bacteriology / Edited by D. Brenner, N. Krieg, J. Staley et al. USA: Springer, 2005.Vol. 2. 922- 925.

17. Kunapuli U., Jahn M. K., Lueders T. et al. Desulfitobacterium aromaticivorans sp. nov. and Geobacter toluenoxydans sp. nov., iron-reducing bacteria capable of anaerobic degradation of monoaromatic hydrocarbons. International Journal of Systematic and Evolutionary Microbiology, 2010; 60: 686-695.

18. Kurdish I.K. The role of microorganisms in rehabilitation of soil fertility. General and Soil Microbiology, 2009; 9: 7-32. (In Ukrainian).

19. Kuzmishyna-Diakiv S., Hnatush S. Microbiota of the Coal Pits Waste Heaps. Saarbrücken, Germany: OmniScriptum GmbH \& Co. KG, Lambert Academic Publishing, 2015. 56 p.

20. Lakin G. Biometrics. Moscow: Vysshaja Shkola, 1990. 352 p. (In Russian).

21. Liesack W., Finster K. Phylogenetic analysis of five strains of gram-negative, obligately anaerobic, sulfur-reducing bacteria and description of Desulfuromusa gen. nov., including $D e$ sulfuromusa kysingii sp. nov., Desulfuromusa bakii sp. nov., and Desulfuromusa succino xidans sp. nov. International Journal of Systematic Bacteriology, 1994; 44 (4):753-758.

22. Lin W.C., Coppi M.V., Lovley D.R. Geobacter sulfurreducens can grow with oxygen as a terminal electron acceptor. Applied and Environmental Microbiology, 2004; 70 (4): 25252528.

23. Lovley D.R. Bioremediation of organic and metal contaminants with dissimilatory metal reduction. Journal of Industrial Microbiology, 1995; 14: 85-93.

24. Lovley D.R. Dissimilatory metal reduction. Annual Review of Microbiology, 1993; 47: 263 290.

25. Lovley D.R., Phillips E.J.P., Lonergan D.J. et al. Fe(III) and $\mathrm{S}^{0}$ Reduction by Pelobacter carbinolicus. Applied and Environmental Eicrobiology, 1995; 61 (6): 2132-2138.

26. Lovley D.R., Giovannoni S.J., White D.C. et al. Geobacter metallireducens gen. nov. sp. nov., a microorganism capable of coupling the complete oxidation of organic compounds to the reduction of iron and other metals. Archives of Microbiology, 1993; 159 (4): 336-344.

27. Lovley, D.R., Ueki T., Zhang T. et al. Geobacter. The Microbe Electric's Physiology, Ecology, and Practical Applications. Advances in Microbial Physiology, 2011; 59: 1-100.

28. LPSN - list of prokaryotic names with standing in nomenclature. [internet-resource]. Access regime: http://www.bacterio.net/deltaproteobacteria.html

29. Nevin K.P., Holmes D.E., Woodard T.L. et al. Reclassification of Trichlorobacter thiogenes as Geobacter thiogenes comb. nov. International Journal of Systematic and Evolutionary Microbiology. 2007; 57: 463-466.

30. Parte A.C. LPSN-list of prokaryotic names with standing in nomenclature. Nucleic Acids Research, 2014; 42 (Database issue), D613-D616.

31. Pfennig N., Biebl H. Desulfuromonas acetoxidans gen. nov. and sp. nov. a new anaerobic, sulfur-reducing, acetate-oxidizing bacterium. Archives of Microbiology, 1976; 110: 150-155.

32. Polanco F.F., Polanco M.F., Uruena M.A. et al. Combining the biological nitrogen and sulphur cycles in anerobic conditions. Water Science Technology, 2001; 44(8): 77-84.

33. Reynolds E.S. The use of lead citrate at high $\mathrm{pH}$ as an electronopaque stain in electron microscopy. Journal of Cell Biology, 1963; 17: 208-212.

ISSN 1996-4536 (print) • ISSN 2311-0783 (on-line) • Біологічні Студії / Studia Biologica • 2016 • Том 10/№2 • C. 63-76 
34. Roden E.E., Lovely D.R. Dissimilatory Fe (III) - reduction by the marine microorganism Desulfuromonas acetoxidans. Applied and Environmental Microbiology, 1993; 59(3): 734-742.

35. Rotaru A.-E., Woodard T.L., Nevin K.P. et al. Link between capacity for current production and syntrophic growth in Geobacter species. Frontiers in Microbiology, 2015: 6, Article 744.

36. Rozanova E. P. Cultivation and identification methods of both sulfur and it's oxygenated compounds reducing anaerobic bacteria. Theoretical and Methodological Foundations of Fnaerobic Microorganisms Study. Pushchino, 1978. 123-136 p. (In Russian).

37. Shelobolina E.S., Vrionis H.A., Findlay R.H. et al. Geobacter uraniireducens sp. nov., isolated from subsurface sediment undergoing uranium bioremediation. International Journal of Systematic and Evolutionary Microbiology, 2008; 58: 1075-1078.

38. Sokolov E. M., Kachurin N. M. Waste heaps of Undermoscow basin reculrivation. TulNU News: Earth Science, 2010; 1: 102-105. (In Russian).

39. Sugio D., Oda C., Matsumoto K. et al. Purification and characterization of sulfur reductase from a moderately thermophilic bacterial strain, $\mathrm{Tl}-1$, that oxidizes iron. Bioscience, Biotechnology, and Biochemistry, 1998; 62 (4): 705-709.

40. Sugiyama $M$. Reagent composition for measuring hydrogen sulfide and method for measuring hydrogen sulfide. United States Patent N 6340596. 2002.

41. Sun D., Wang A., Cheng S. et al. Geobacter anodireducens sp. nov., an exoelectrogenic microbe in bioelectrochemical Systems. International Journal of Systematic and Evolutionary Microbiology, 2014; 64: 3485-3491.

42. Tepper E.Z., Shelnikova V.K., Pereverzeva G.I. Practical Microbiology, $3^{\text {rd }}$ ed. Moscow: Agropromizdat, 1987. 239 p. (In Russian).

43. Vandieken V., Mussmann M. Niemann H. et al. Desulfuromonas svalbardensis sp. nov. and Desulfuromusa ferrireducens sp. nov., psychrophilic, Fe(III)-reducing bacteria isolated from Arctic sediments, Svalbard. International Journal of Systematic and Evolutionary Microbiology, 2006; 56: 1133-1139.

44. Yang T. H., Coppi M. V., Lovley D. R. et al. Metabolic response of Geobacter sulfurreducens towards electron donor/acceptor variation. Microbial Cell Factories, 2010.

45. Zavarzina D. G., Kolganova T. V., Bulygina E. S. et al. Geoalkalibacter ferrihydriticus gen. nov., sp. nov., the first alkaliphilic representative of the family Geobacteraceae, isolated from a soda lake. Mikrobiologiia, 2006; 75(6):775-85.

46. Zhou S., Yang G., Lu Q. et al. Geobacter soli sp. nov., a dissimilatory Fe(III)-reducing bacterium isolated from forest soil. International Journal of Systematic and Evolutionary Microbiology, 2014; 64: 3786-3791.

\title{
СІРКОВІДНОВЛЮВАЛЬНІ БАКТЕРІЇ ПОРОДНИХ ВІДВАЛІВ ВУГІЛЬНИХ ШАХТ ЧЕРВОНОГРАДСЬКОГО ГІРНИЧОПРОМИСЛОВОГО РАЙОНУ
}

\author{
С. В. Дяків ${ }^{1}$, С. О. Гнатуші ${ }^{1}$, О. М. Мороз ${ }^{1}$, О. Я. Припін \\ О. Р. Кулачковський ${ }^{1}$ В. Є. Боднарук \\ 1 Львівський національний університет імені Івана Франка \\ вул. Грушевського, 4, Львів 79005, Україна \\ e-mail:kuzmishyna_s_@ukr.net \\ ${ }^{2}$ Львівський національний університет ветеринарної медицини та біотехнологій \\ імені С. З. Ґжицького, вул. Пекарська, 50, Львів 79010, Україна
}

Із порід відвалів вугільних шахт Червоноградського гірничопромислового району виділені сірковідновлювальні бактерії та досліджено сезонні зміни їхньої чи- 
сельності. Встановлено, що кількість сірковідновлювальних бактерій зростає у холодні пори року та по закінченні вегетаційного сезону і залежить від вологості породи й температури субстрату. Виділено 40 культур сірковідновлювальних бактерій. Відповідно до накопичення найвищої біомаси та продукції гідроген сульфіду для ідентифікації відібрано 2 штами. Досліджено морфофрізіологічні характеристики виділених штамів СВ 30 та СВ 35. Відповідно до отриманих даних припускаємо, що виділений штам СВ 30 належить до роду Desulfuromusa, a CB 35 - Geobacter. Найвищу сульфідогенну активність виділених культур виявили після сьомої доби культивування. За здатністю метаболізувати широкий спектр полютантів виділені сірковідновлювальні бактерії, перспективні для використання у технологіях ремедіації середовищ біологічними методами.

Ключові слова: сірковідновлювальні бактерії, Geobacter, Desulfuromusa, породні відвали вугільних шахт.

\title{
СЕРОВОССТАНАВЛИВАЮЩИЕ БАКТЕРИИ С ПОРОД ОТВАЛОВ УГОЛЬНЫХ ШАХТ ЧЕРВОНОГРАДСКОГО ГОРНОПРОМЫШЛЕННОГО РЕГИОНА
}

\author{
С. В. Дякив ${ }^{1}$, С. А. Гнатуші ${ }^{1}$, О. М. Мороз ${ }^{1}$, О. Я. Прыпин \\ О. Р. Кулачковский' , В. Е. Боднарук \\ 1 Львовский национальный университет имени Ивана Франко \\ ул. Грушевского, 4, Львов 79005, Украина \\ e-mail: kuzmishyna_s_@ukr.net
}

${ }^{2}$ Львовский национальный университет ветеринарной медицины и биотехнологий имени С. З. Гжицкого, ул. Пекарская, 50, Львов 79010, Украина

С пород отвалов угольных шахт Червоноградского горнопромышленного района выделены серовосстанавливающие бактерии и исследованы изменения их численности. Установлено, что количество серовосстанавливающих бактерий возрастает в холодное время года и по окончании вегетационного сезона и зависит от влажности породы и температуры субстрата. Выделены 40 культур серовосстанавливающих бактерий. В соответствии с накоплением самой высокой биомассы и продукции гидроген сульфида для идентификации выбраны 2 штамма. Исследованы морфофризиологические характеристики виделенных штаммов СВ 30 и СВ 35. В соответствии с полученными данными выделенный штамм СВ 30 определен до рода Desulfuromusa, a CB 35 - Geobacter. Самую высокую сульфидогенную активность выделенных культур обнаружили после седьмых суток культивирования. По способности метаболизировать широкий спектр поллютантов виделенные серовосстанавливающие бактерии являются перспективными для использования в технологиях ремедиации среды с помощью биологических методов.

Ключевые слова: серовосстанавливающие бактерии, Geobacter, Desulfuromusa, породные отвалы угольных шахт

Одержано: 30.05.2016

ISSN 1996-4536 (print) • ISSN 2311-0783 (on-line) • Біологічні Студії / Studia Biologica • 2016 • Том 10/№2 • С. 63-76 